\title{
DIETARY EFFECT OF MULBERRY LEAF (Morus alba) MEAL ON GROWTH PERFORMANCE AND SERUM CHOLESTEROL LEVEL OF BROILER CHICKENS
}

\author{
M. R. Islam, M. Nurealam Siddiqui ${ }^{* 1}$, A. Khatun, M. N. A. Siddiky ${ }^{2}$ \\ M. Z. Rahman, A. B. M. R. Bostami ${ }^{3}$ and A. S. M. Selim ${ }^{3}$ \\ Department of Dairy and Poultry Science, Hajee Mohammad Danesh Science \& \\ Technology University, Dinajpur-5200, Bangladesh
}

\begin{abstract}
To investigate the effect of dietary mulberry leaf meal on body weight, feed conversion efficiency and blood cholesterol level, 240 day-old broiler chicks (Cobb 500) were divided into 6 treatments, each with 4 replications (10 birds/ per replicate) and offered manually prepared diets supplemented with 2.5, 3.5, 4.5\% mulberry leaf meal (MLM), MLM Extract and $0.5 \%$ for a period of six weeks. Average body weight $(\mathrm{g})$ gain increased $(P>0.05)$ at 2.5 or $4.5 \%$ supplementation of MLM and with MLM extract compared to control and antibiotic group. Feed conversion ratio was better at $4.5 \%$ supplementation (1.67) and on addition of MLM extract (1.63) compare to control (1.79). Total cholesterol, HDLcholesterol and triglyceride of broiler chicks in different dietary treatments of during experimental periods were non-significant at day 10 to 15 but total cholesterol and triglyceride decreased significantly $(P>0.05)$ at $d 15$ to 22 compared to control and antibiotic group. Significant $(P<0.05)$ reduction of total cholesterol and triglyceride with supplementation of mulberry leaf meal at 2.5, 3.5, 4.5\% MLM, MLM extract were also observed at $d 22$ to 42 compared to control and antibiotic group. The result suggests that inclusion of mulberry leaf meal (both 3.5\% powder and extract) may be used to formulate low-cost broiler grower diet in order to produce low-cholesterol broiler meat.
\end{abstract}

Key Words: Mulberry Leaf Meal (MLM), Antibiotic, Broiler, Serum cholesterol

\footnotetext{
* Corresponding author email: nuralam_hstu@yahoo.com

${ }^{1}$ Department of Biochemistry and Molecular Biology, Bangabandhu Sheikh Mujibur Rahman Agricultural University, Gazipur-1706, Bangladesh

${ }^{2}$ SAARC Agriculture Centre, Farmgate, Dhaka-1215, Bangladesh

${ }^{3}$ Department of Animal Science and Nutrition, Bangabandhu Sheikh Mujibur Rahman Agricultural University, Gazipur-1706, Bangladesh
}

Received: 27.04.2014 


\section{INTRODUCTION}

The cost of feed constitutes is the major proportion between $60-75 \%$ of the total cost of poultry production and protein cost account for over $40 \%$ of the total feed cost in livestock and poultry farming (Ojewola et al., 2005). Besides, the price of conventional protein feeds resources such as groundnut cake, fish meal and soybean meal are in high cost and cannot permit profit maximization in poultry ventures. In view of this, current research interest in the poultry industry is aimed at finding alternatives to this elusive feed ingredient. The list of possible feed alternatives includes tree fodder mulberry leaves (Morus alba) as a source of dietary protein for commercial livestock and poultry operations. Mulberry grows well in the tropics and subtropics, and is reported to have excellent nutritional value as forage. It is grown extensively for its leaves, which are used for raising silkworms in the sericulture industry. Mulberry leaves are rich in protein (15-35\%), minerals (2.42$4.71 \% \mathrm{Ca}, 0.23-0.97 \% \mathrm{P})$ and metabolizable energy $\left(1,130-2,240 \mathrm{kcal} \mathrm{kg}^{-1}\right)$ with absence of or negligible anti-nutritional factors (Omar et al., 1999; Sarita et al., 2006). Mulberry leaves contain $\beta$-carotene, which can be converted with varying efficiency by animals to vitamin A and the xanthophylls, which can be a good source of the pigmentation of egg yolk (Sarita et al., 2006). Excellent results have been obtained with using mulberry leaves as ruminant feed (Rojas and Benavides, 1994; Gonzalez et al., 1996; Omar et al., 1999). Information on feeding mulberry to nonruminants is scanty but it has been used in pigs (Trigueros and Villalta, 1997), laying hens (Narayana and Setty, 1977), and rabbits (Deshmukh et al., 1993). Dot et al. (2000) demonstrated that the intake of mulberry leaves reduced the concentration of serum lipids and atheromatous thickening of arterial intima in hypercholesterolemic rabbits. Although much work has been done on the utilization of rats, mice and rabbits, reports on the use of mulberry leaves in poultry feeds are limited. Thus there is a need to study the effect of mulberry leaves inclusion in poultry diets on production performance, cholesterol and triglyceride in blood, meat and egg.

Antibiotics as feed additives have been used for years. Antibiotics have also been widely used in animal feed in many other countries although a number of individual countries and the European Union have restricted the sub therapeutic use of some antibiotics (Aarestrup, 2000). So, there is a great interest in developing natural alternatives to antibiotic growth promoters in order to maintain both bird performance and health (Cross et al., 2007). As a result, numerous medicinal herbs have been suggested to livestock producers as alternatives to antibiotic growth promoters (Doyle, 2001). Several researchers have reported the possibility of growthpromoting and antioxidative effects for some traditional medicinal herbs (Liu et al., 2006). These medicinal herbs are considered to be natural products, so consumers may willingly allow them to be included in livestock feeds. Thus the objective of the present experiment was to evaluate the effect of graded level of mulberry leaf meal in the broiler diets in order to observe the performance, feed efficiency and cholesterol level. 


\section{MATERIALS AND METHODS}

\section{Preparation of Morus alba leaf powder}

Morus alba was collected from local area of Dinajpur district in Bangladesh. The leaves were sundried, coarsely powdered manually and then directly mixed with manually prepared diets in appropriate doses (Table 1, $2 \& 3$ ).

\section{Preparation of other feed ingredients}

Sundried and grinded corns, meat meal, bone meal, rice polish, soybean meal, soybean oil and other feed items were collected from local market of Dinajpur, Bangladesh and then directly mixed with manually prepared diets in appropriate doses (Table 1, $2 \& 3$ ). Vitamin premix used in the formulated diets was made of reputed veterinary Medicine Company.

\section{Birds and experimental design}

A total of 240 one day-old broiler chick (Cobb 500) were reared at brooding house to adjust with the environmental condition up to 10 days. After that, chicks were randomly allocated to six dietary treatment groups having 40 birds in each group; each treatment was composed of four replicates with 10 birds in each in a complete randomized design. The birds were housed on floor and routinely managed as any other commercial broiler flock. Heating was provided by a single electric brooder, where the initial temperature was set at $32{ }^{\circ} \mathrm{C}$ and decreased by $2{ }^{\circ} \mathrm{C}$ per week to final temperature of $20^{\circ} \mathrm{C}$ at the end of experiment.

\section{Experimental diets}

The experimental diets in mash form and drinking water was provided adlibitum. All the diets were formulated manually to meet the nutrient requirements of broiler (NRC, 1994). The chicks were fed starter diet from 1 to 10 days, grower diet from 11-20 days and a finisher diet from 21 to 42 days old broiler (Table 1, 2 \&3). Diets were analyzed for dry matter, crude protein, crude fibre and crude fat according to the AOAC (1980) methods. The experimental diets were designed as $\mathrm{T}_{0}=$ control, $\mathrm{T}_{1}=2.5 \% \mathrm{MLM}, \mathrm{T}_{2}=3.5 \% \mathrm{MLM}, \mathrm{T}_{3}=4.5 \% \mathrm{MLM}, \mathrm{T}_{5}=$ MLM Extract and $\mathrm{T}_{5}=0.5 \%$ antibiotic (oxytetracycline, Trade name ${ }^{\circledR}$, Renata Ltd)

\section{Observation of birds}

All birds were examined twice daily for any visible physical changes like restlessness, lordosis, abnormal gait, vices and depression as well as changes of feeding style during treatment. All birds were vaccinated against Newcastle and Gumboro as per instruction of the manufacturers.

\section{The performance trial}

Initial body weight was recorded before the on set of the trial. Then body weight and feed consumption were recorded daily. Final weight of the birds was also recorded. These data were used to calculate body weight gain and feed conversion ratio. 


\section{Blood collection and estimation of serum lipid profile}

The blood was collected at the last date of the experiment from each group (3 birds) with a syringe and needle directly through wing vein puncture without using any anticoagulant. After centrifugation of the clotted blood, the supernatant was carefully collected by a micropipette and preserved in eppendrof vial. The collected serum was stored at $-15^{\circ} \mathrm{C}$ until estimation of total cholesterol, high-density lipoprotein (HDL)-cholesterol and triglycerides using lipid profile kit (Crescent Diagnostics).

\section{Statistical Analysis}

The data was analyzed by using the MSTATC program. Differences among treatments, when significant, were also ordered using Tukey's test (Kuehl, 1994). Statements of statistical significance were based on $\mathrm{P}<0.05$ or $\mathrm{P}<0.01$.

\section{RESULTS AND DISCUSSION}

\section{Body weight gain, feed consumption and feed efficiency of the birds}

The average body weight gain and total feed consumption of the birds fed different formulated MLM and antibiotic diets has been shown in table 4. The results shows that average body weight gain did not increased significantly while supplemented with different doses of MLM and antibiotic diets. However, average body weight gain increased more than $15 \%$ in MLM supplemented diets compared to control (To) and antibiotic fed group $\left(\mathrm{T}_{5}\right)$. This result is in agreement with Panja (2013) who observed non significant improvement of body weight gain in broilers supplemented with mulberry leaves at $0,0.5,1.0,1.5$ and $2.0 \%$ of diet. This might be because all diets were isocaloric and isonitrogenous (Tan et al., 1988). The average feed consumption ranged $2300-2700 \mathrm{~g}$ was also non-significant among treatments. This result is similar to Seeang (2001) and Simol et al. (2012) who reported that the supplementation of mulberry leaves in the layer diets had no effects on feed intake. Besides, Panja (2000) showed that native chicken and hybrid native chicken which received the same diet also had no effects on the feed consumption.

The feed conversion ratio (FCR) of birds fed different diets has been indicated in the Table 4. The results indicate that FCR could not affect by the supplemented diets. However, FCR was better at $\mathrm{T}_{4}$ (1.63) followed by $\mathrm{T}_{3}$ (1.67), $\mathrm{T}_{1}(1.80), \mathrm{T}_{2}$ (1.81), $\mathrm{T}_{0}$ (1.83) and $\mathrm{T}_{5}$ (1.90). Similar results were also obtained by Simol et al. (2012) who showed that mulberry leaf powder can substitute up to $30 \%$ of commercial feed without any adverse effect on the feed intake, growth and FCR of the broiler chicken. But improvement of FCR might be due to stimulation of digestive enzymes followed by better digestion and utilization of feed. Moreover, dietary interactions between fat-protein, protein-minerals or minerals-fats may create the differences. It is known that high fibre content reduces feed intake in broilers (Janssen and Carré, 1985) but the better amino acid composition in mulberry leaves (Al-Kirshi et al., 2010) could have compensated for this effect. 


\section{Serum lipid profile contents of broilers}

The effects of MLM supplemented diets on serum lipids like total cholesterol, HDL-cholesterol, and triglycerides of broilers are shown in table 5. Total cholesterol, HDL-cholesterol and triglyceride of broiler chicks in different dietary treatments during experimental periods were almost statistically similar and the differences were not significant $(\mathrm{P}<0.05)$ from 10 to 15 days. However, from the table $(5)$, it was observed that the values of total cholesterol level in $T_{3}, T_{2}, T_{1}, T_{4}$ groups were 130.7, $91.67 \mathrm{mg} \mathrm{dl}^{-1}, 141.7$ and116.3 respectively. All the values were found to be lower than that of control groups $\mathrm{T}_{0}\left(168.0 \mathrm{mg} \mathrm{dl}^{-1}\right), \mathrm{T}_{5}\left(164.3 \mathrm{mg} \mathrm{dl}^{-1}\right)$ and significantly differing from other groups. In the $\mathrm{T}_{2}$ and $\mathrm{T}_{4}$ groups i.e. both $3.5 \%$ MLM supplemented and their acetone extract was found total cholesterol content significantly lower than that of control fed groups. Total cholesterol and triglyceride were significantly reduced compared to control and antibiotic group (Table 5). Similar results were reported by Panja (2000) who supplemented with mulberry leaves at $0,0.5,1.0,1.5$ and $2.0 \%$ of diet in broiler. This is perhaps because of its crude fiber content. Balmer and Zilversmit (1974) reported that fiber is an indigestible feed component affecting cholesterol metabolism and concentration of cholesterol in blood. Tasi et al. (1976) reported serum cholesterol levels in rats decreased as dietary fiber content increased. Similar results were observed in laying hens (Menge et al., 1974). Similarly, Kawrhung (1996) reported that rabbits fed a high cholesterol diet and mulberry leaves at $2.5 \%$, showed a decrease in the levels of cholesterol in their blood by a half during 10 weeks.

\section{CONCLUSION}

From above observation, it may be concluded that the MLM supplemented diets had limited effect on mortality rate and had no detrimental effect on fat content. The performances of broiler i.e., final body weight, feed intake, and feed conversion ratio were improved by feeding MLM supplemented diets at different levels. The positive effect of these was on serum lipids. Among the MLM supplemented diets, our findings suggest that supplementation of both 3.5\% MLM powder and extracts of MLM has high potential as commercial applications for production of lowcholesterol and healthy broilers.

\section{REFERENCES}

Aarestrup, F.M. 2000. Occurrence, selection and spread of resistance to antimicrobial agents used for growth promotion for food animals in Denmark. APMIS, 108 (Suppl. 101):548

Al-Kirshi, R.A., Alimon, A.R., Zulkifli, I., Sazili, A.Q., Zahari, W.M., Ivan, M. 2010. Utilization of mulberry leaf meal (Morus alba) as protein supplement in diets for laying hens. Italy Journal of Animal Science, 9:51 
AOAC, 1980. Association of official analytical chemists, official methods of analysis. $13^{\text {th }}$ Edition. Washington, DC

Balmer, J. and Zilversmit, D.B. 1974. Effect of dietary roughage on cholesterol absorption, cholesterol turnover and steroid excretion in the rat. Journal of Nutrition, 104, 1319-28

Cross, D.E., McDevitt, R.M., Hillman, K. and Acamovic, T. 2007. The effect of herbs and their associated essential oils on performance, dietary digestibility and gut microflora in chickens from 7 to 28 days of age. British Poultry Science, 48: 496-506

Deshmukh, S.V., Pathak, N.V. and Takalikah, D. A. 1993. Nutritional effect of mulberry (Morus alba) leaves as sole ration of adult rabbits. World Rabbit Science, 1:67-69

Dot, K., Kojima, T. and Fujimoto, Y. 2000. Mulberry leaves extract in habits the oxidative modification of rabbit and human low density lipoprotein. Biological \& Pharmaceutical Bulletin, 23:1066-71

Doyle, M.E. 2001. Alternatives to antibiotic use for growth promotion in animal husbandry. FRI BRIEFINGS, http://fri.wisc.edu/docs/pdf/antibiot.pdf

Gonzalez, C., Tepper, R. and Ly, J. 1998. An approach to the study of the nutritive value of mulberry leaf and palm oil in growing pigs. Revista Cientifica, ISSN 0798-2259

Janssen, W.M.M.A. and Carré, B. 1985. Influence of fiber on digestibility of broiler feeds. In Recent Advances in Animal Nutrition, DJA Cole and W Haresign, eds (ButterworthHeinemann, London) pp. 78-93

Kawrhung, W.1996. Utilization and Products of Mulberry, Mulberry and Silk Research Institute Department of Agriculture Minister of Agriculture and Cooperation, Bangkok, p. 24

Kuehl, R.O. 1994. Statistical principles of research design and analysis. Duxbury press, Belmont, CA, pp 686

Liu, J. X., Yao, J., Yan, B. and Wang, X. Q. 2006. Nutritional evaluation of mulberry leaves as feeds for ruminants. Livestock Research for Rural Development, 12:125-131

Menge, H., LittleField L.H., Frobish, L.T. and Weinland, B.T. 1974 Effect of cellulose and cholesterol on blood and yolk lipids and reproductive efficiency of the hen. Journal of Nutrition, 104:1554-6

Narayana, H. and Setty, S. V. S. 1977. Studies on the incorporation of mulberry (Morus indica) leaves in layers mash on health, production and egg quality. Indian Journal of Animal Science, 47: 212-215

National Research Council (NRC), 1994. Nutrient Requirements of Poultry.9th rev. ed. National Academy Press, Washington, DC, USA

Ojewola, G. S., Okoye, F. C. and Ukoha, O. A. 2005. Comparative utilization of three animal protein sources by broiler chickens. International Journal of Poultry Science, 4970: $462-467$

Omar, S.S., Shayo, C.M. and Uden, P. 1999. Voluntary intake and digestibility of mulberry (Morus alba) diets by growing goats. Tropical Grasslands, 33: 177-181 
Panja P. 2013. The Effects of Dietary Mulberry Leaves (Morus alba L.) on Chicken Performance, Carcass, Egg Quality and Cholesterol Content of Meat and Egg. Walailak Journal of Science \& Technology, 10(2): 121-129

Panja, P. 2000. Study on growth performance and carcass quality of native and hybrid Native chickens. Thammasat International Journal of Science and Technology, 8: 39-43

Rojas, H. and Benavides, J.E. 1994. Produccion deleche de cabras alimentadas con pastro y suplementadas con altos niveles de morera (Morus sp.) In: Benavides, J.E. (ed.) Arboles y arbustos forrajeros en America Central. Volumen I. CATIE, Turrialba, Costa Rica, 305-317

Sarita, S., Rashmi, K., Anju, T. and Prakash, R. 2006. Nutritional quality of leaves of some genotypes of mulberry (Morus alba). International Journal of Food Science and Nutrition, 57: 305-313

Seeang, S. 2001, The study of Mulberry Leaves as a Protein Supplement in Layer Diet. M. Sc. Thesis. Kasetsart Univ, Bangkok, p. 44

Simol, C.F., Tuen, A.A., Khan, H.H.A., Chubo, J.K., King, P.J.H. and Ong, K.H. 2012. Performance of chicken broilers fed with diets substituted with mulberry leaf powder. African Journal of Biotechnology, 11: 16106-16111

Tan, J.Z., Chen H.I. and Zeng, A.Q. 1988. Energy and protein requirement of putain laying duck. Chinese Journal of Animal Science, 6:3-8

Tasi, A.C., Elies, J., Kely, J.J., Lin, R.S. and Robson, J.R. 1976. Influence of certain dietary fibers on serum and tissue cholesterol levels in rats. Journal of Nutrition, 106:118-23.

Trigueros, R. O. and Villalta, P. 1997. Nutritive evaluation of mulberry leaf (Morus alba). National Center of Agriculture, Livestock and Forestry Technology (CENTA) ed., San Salvador, El Salvador, 150-155 
Table 1: Composition of experimental starter diets fed to broilers

\begin{tabular}{|c|c|c|c|c|c|c|}
\hline \multirow{2}{*}{$\begin{array}{c}\text { Items } \\
\text { Feed ingredients } \\
(\mathrm{kg} / 100 \mathrm{~kg} \text { feed })\end{array}$} & \multicolumn{5}{|c|}{ Dietary level of Mulberry leaf meal (MLM) } & \multirow[b]{2}{*}{$\begin{array}{c}\mathrm{T}_{5}, \mathrm{~kg} \\
(0.5 \% \\
\text { Antibiotic })\end{array}$} \\
\hline & $\begin{array}{c}\mathrm{T}_{0}, \mathrm{~kg} \\
\text { (control) }\end{array}$ & $\begin{array}{l}\mathrm{T}_{1}, \mathrm{~kg} \\
(3.5 \% \\
\text { MLM) }\end{array}$ & $\begin{array}{l}\mathrm{T}_{2}, \mathrm{~kg} \\
(3.5 \% \\
\text { MLM })\end{array}$ & $\begin{array}{l}\mathrm{T}_{3}, \mathrm{~kg} \\
(4.5 \% \\
\text { MLM) } \\
\end{array}$ & $\begin{array}{c}\mathrm{T}_{4}, \mathrm{~kg} \\
(\mathrm{MLM} \\
\text { Extract) }\end{array}$ & \\
\hline Maize & 52.00 & 50.00 & 50.00 & 50.00 & 50.00 & 50.00 \\
\hline Soybean meal & 23.00 & 24.00 & 23.00 & 22.50 & 22.50 & 22.50 \\
\hline Rice polish & 14.50 & 14.50 & 14.00 & 14.00 & 14.00 & 14.00 \\
\hline Soybean Oil & 0.50 & 0.50 & 0.50 & 0.50 & 0.50 & 0.50 \\
\hline Salt & 0.25 & 0.25 & 0.25 & 0.25 & 0.25 & 0.25 \\
\hline Methionine & 0.25 & 0.25 & 0.25 & 0.25 & 0.25 & 0.25 \\
\hline Lysine & 0.01 & 0.01 & 0.01 & 0.01 & 0.01 & 0.01 \\
\hline Growth promoter & 0.50 & 0.50 & 0.50 & 0.50 & 0.50 & 0.50 \\
\hline Protein & 9.00 & 7.50 & 8.00 & 7.500 & 7.500 & 8.00 \\
\hline $\begin{array}{l}\text { MLM } \\
\text { concentrate }\end{array}$ & 0.00 & 2.50 & 3.50 & 4.50 & 3.50 & 0.00 \\
\hline Antibiotic & 0.00 & 0.00 & 0.00 & 0.00 & 0.00 & 0.50 \\
\hline $\begin{array}{l}\text { Vitamin Mineral } \\
\text { Premix }\end{array}$ & 0.25 & 0.25 & 0.250 & 0.25 & 0.25 & 0.25 \\
\hline \multicolumn{7}{|l|}{$\begin{array}{l}\text { Chemical } \\
\text { composition }\end{array}$} \\
\hline $\operatorname{ME}\left(\mathrm{kcal} \mathrm{kg}^{-1}\right)$ & 3085 & 3120 & 3100.5 & 3080 & 3140 & 3095 \\
\hline $\mathrm{CP}\left(\mathrm{gm} \mathrm{kg}^{-1}\right)$ & 21.35 & 21.3 & 21.4 & 21.5 & 21.25 & 21.45 \\
\hline $\mathrm{CF}\left(\mathrm{gm} \mathrm{kg}^{-1}\right)$ & 3.75 & 3.77 & 3.72 & 3.75 & 3.77 & 3.77 \\
\hline $\mathrm{Ca}\left(\mathrm{gm} \mathrm{kg}^{-1}\right)$ & 1.12 & 1.13 & 1.12 & 1.11 & 1.13 & 1.12 \\
\hline $\mathrm{P}\left(\mathrm{gm} \mathrm{kg}^{-1}\right)$ & 0.56 & 0.56 & 0.56 & 0.54 & 0.58 & 0.56 \\
\hline $\begin{array}{l}\text { Methionine } \\
\left(\mathrm{gm} \mathrm{kg}^{-1}\right)\end{array}$ & 0.48 & 0.48 & 0.48 & 0.48 & 0.48 & 0.48 \\
\hline Lysine $\left(\mathrm{gm} \mathrm{kg}^{-1}\right)$ & 1.18 & 1.18 & 1.19 & 1.18 & 1.19 & 1.19 \\
\hline
\end{tabular}

Added broiler premix (Renata Animal Health Ltd.) @ 250 g per 100 kg which contained: vitamin A: $4800 \mathrm{IU}$; vitamin D: $960 \mathrm{IU}$; vitamin E: $9.2 \mathrm{mg}$; vitamin $\mathrm{k}_{3}: 800 \mathrm{mg}$; vitamin $\mathrm{B}_{1}: 600 \mathrm{mg}$; vitamin $\mathrm{B}_{2}: 2$ $\mathrm{mg}$; vitamin $\mathrm{B}_{3}: 12 \mathrm{mg}$; vitamin $\mathrm{B}_{5}: 3.2 \mathrm{mg}$; vitamin $\mathrm{B}_{6}: 1.8 \mathrm{mg}$; vitamin $\mathrm{B}_{9}: 2 \mathrm{mg}$; vitamin $\mathrm{B}_{12}: 0.004$ mg; Co: $0.3 \mathrm{mg}$; Cu: $2.6 \mathrm{mg}$; Fe: $9.6 \mathrm{mg}$; I: $0.6 \mathrm{mg}$; Mn: $19.2 \mathrm{mg}$; Zn: $16 \mathrm{mg}$; Se: $0.48 \mathrm{mg}$; DL Methionine: $20 \mathrm{mg}$; L- lysine: $12 \mathrm{mg}$. 
Table 2: Composition of the experimental grower diets fed to broilers

\begin{tabular}{|c|c|c|c|c|c|c|}
\hline \multirow{2}{*}{$\begin{array}{l}\text { Items } \\
\text { Feed ingredients } \\
(\mathrm{kg} / 100 \mathrm{~kg} \text { feed })\end{array}$} & \multicolumn{6}{|c|}{ Dietary level of Mulberry leaf meal (MLM) } \\
\hline & $\begin{array}{l}\mathrm{T}_{0}, \mathrm{~kg} \\
\text { (control) }\end{array}$ & $\begin{array}{l}\mathrm{T}_{1}, \mathrm{~kg} \\
(2.5 \% \\
\text { MLM) }\end{array}$ & $\begin{array}{l}\mathrm{T}_{2}, \mathrm{~kg} \\
(3.5 \% \\
\text { MLM) }\end{array}$ & $\begin{array}{l}\mathrm{T}_{3}, \mathrm{~kg} \\
(4.5 \% \\
\text { MLM })\end{array}$ & $\begin{array}{l}\mathrm{T}_{4}, \mathrm{~kg} \\
\text { (MLM } \\
\text { Extract) }\end{array}$ & $\begin{array}{l}\mathrm{T}_{5}, \mathrm{~kg} \\
(0.5 \% \\
\text { Antibiotic })\end{array}$ \\
\hline Maize & 53.00 & 52.00 & 52.00 & 52.00 & 52.50 & 53.00 \\
\hline Soybean meal & 22.00 & 20.50 & 20.50 & 21.50 & 21.00 & 22.00 \\
\hline Rice polish & 14.50 & 14.50 & 14.00 & 13.00 & 13.50 & 14.50 \\
\hline Soybean Oil & 0.50 & 0.50 & 0.50 & 0.50 & 0.50 & 0.50 \\
\hline Salts & 0.25 & 0.25 & 0.25 & 0.25 & 0.25 & 0.25 \\
\hline Methionine & 0.25 & 0.25 & 0.25 & 0.25 & 0.25 & 0.25 \\
\hline Lysine & 0.01 & 0.01 & 0.01 & 0.01 & 0.01 & 0.01 \\
\hline Growth promoter & 0.50 & 0.50 & 0.50 & 0.50 & 0.50 & 0.50 \\
\hline Protein & 9.00 & 9.00 & 8.50 & 7.50 & 8.50 & 9.00 \\
\hline MLM concentrate & 0.00 & 2.50 & 3.50 & 4.50 & 3.50 & 0.00 \\
\hline Antibiotic & 0.00 & 0.00 & 0.00 & 0.00 & 0.00 & 0.50 \\
\hline Vitamin Mineral Premix & 0.25 & 0.25 & 0.25 & 0.25 & 0.25 & 0.25 \\
\hline \multicolumn{7}{|l|}{ Chemical composition } \\
\hline $\mathrm{ME}\left(\mathrm{kcal} \mathrm{kg}^{-1}\right)$ & 3098 & 3130.5 & 3110.5 & 3080 & 3140 & 3107.5 \\
\hline $\mathrm{CP}\left(\mathrm{gm} \mathrm{kg}^{-1}\right)$ & 20.6 & 19.5 & 21 & 21.3 & 19.5 & 21.3 \\
\hline $\mathrm{CF}\left(\mathrm{gm} \mathrm{kg}^{-1}\right)$ & 3.77 & 3.78 & 3.76 & 3.77 & 3.78 & 3.78 \\
\hline $\mathrm{Ca}\left(\mathrm{gm} \mathrm{kg}^{-1}\right)$ & 1.18 & 1.15 & 1.16 & 1.15 & 1.16 & 1.13 \\
\hline $\mathrm{P}\left(\mathrm{gm} \mathrm{kg}^{-1}\right)$ & 0.59 & 0.57 & 0.58 & 0.57 & 0.58 & 0.57 \\
\hline Methionine $\left(\mathrm{gm} \mathrm{kg}^{-1}\right)$ & 0.48 & 0.43 & 0.43 & 0.43 & 0.43 & 0.48 \\
\hline Lysine $\left(\mathrm{gm} \mathrm{kg}^{-1}\right)$ & 1.05 & 1.06 & 1.05 & 1.05 & 1.06 & 1.05 \\
\hline
\end{tabular}

Added broiler premix (Renata Animal Health Ltd.) @ 250 g per 100 kg which contained: vitamin A: $4800 \mathrm{IU}$; vitamin D: $960 \mathrm{IU}$; vitamin E: $9.2 \mathrm{mg}$; vitamin $\mathrm{k}_{3}: 800 \mathrm{mg}$; vitamin $\mathrm{B}_{1}: 600 \mathrm{mg}$; vitamin $\mathrm{B}_{2}: 2$ $\mathrm{mg}$; vitamin $\mathrm{B}_{3}: 12 \mathrm{mg}$; vitamin $\mathrm{B}_{5}: 3.2 \mathrm{mg}$; vitamin $\mathrm{B}_{6}: 1.8 \mathrm{mg}$; vitamin $\mathrm{B}_{9}: 2 \mathrm{mg}$; vitamin $\mathrm{B}_{12}: 0.004$ mg; Co: $0.3 \mathrm{mg}$; Cu: $2.6 \mathrm{mg}$; Fe: $9.6 \mathrm{mg}$; I: $0.6 \mathrm{mg}$; Mn: $19.2 \mathrm{mg}$; Zn: $16 \mathrm{mg}$; Se: $0.48 \mathrm{mg}$; DL Methionine: $20 \mathrm{mg}$; L- lysine: $12 \mathrm{mg}$. 
Table 3: Composition of the experimental finisher diets fed to broilers

\begin{tabular}{|c|c|c|c|c|c|c|}
\hline \multirow{4}{*}{$\begin{array}{l}\text { Items } \\
\text { Feed ingredients } \\
(\mathrm{kg} / 100 \mathrm{~kg} \text { feed })\end{array}$} & \multicolumn{6}{|c|}{ Dietary level of Mulberry leaf meal (MLM) } \\
\hline & $\mathrm{T}_{0}, \mathrm{~kg}$ & $\mathrm{~T}_{1}, \mathrm{~kg}$ & $\mathrm{~T}_{2}, \mathrm{~kg}$ & $\mathrm{~T}_{3}, \mathrm{~kg}$ & $\mathrm{~T}_{4}, \mathrm{~kg}$ & $\mathrm{~T}_{5}, \mathrm{~kg}$ \\
\hline & (control) & $(2.5 \%$ & $(3.5 \%$ & $(4.5 \%$ & (MLM & $(0.5 \%$ \\
\hline & & MLM) & MLM) & MLM) & Extract) & Antibiotic) \\
\hline Maize & 55.00 & 55.00 & 55.00 & 55.00 & 55.00 & 55.00 \\
\hline Soybean meal & 20.00 & 20.00 & 20.00 & 21.50 & 19.00 & 20.50 \\
\hline Rice polish & 14.50 & 14.50 & 12.50 & 11.00 & 13.00 & 13.50 \\
\hline Soybean Oil & 0.50 & 0.50 & 0.50 & 0.50 & 0.50 & 0.50 \\
\hline Salt & 0.25 & 0.25 & 0.25 & 0.25 & 0.25 & 0.25 \\
\hline Methionine & 0.25 & 0.25 & 0.25 & 0.25 & 0.25 & 0.25 \\
\hline Lysine & 0.02 & 0.02 & 0.02 & 0.02 & 0.02 & 0.02 \\
\hline Growth promoter & 0.50 & 0.50 & 0.50 & 0.50 & 0.50 & 0.50 \\
\hline Protein & 9.00 & 9.00 & 7.50 & 7.00 & 8.50 & 9.00 \\
\hline MLM concentrate & 0.00 & 2.50 & 3.50 & 4.50 & 3.50 & 0.00 \\
\hline Antibiotic & 0.00 & 0.00 & 0.00 & 0.00 & 0.00 & 0.50 \\
\hline Vitamin Mineral Premix & 0.25 & 0.25 & 0.25 & 0.25 & 0.25 & 0.25 \\
\hline \multicolumn{7}{|l|}{ Chemical composition } \\
\hline $\operatorname{ME}\left(\mathrm{kcal} \mathrm{kg}^{-1}\right)$ & 3115 & 3130.5 & 3140.5 & 3125 & 3170 & 3130 \\
\hline $\mathrm{CP}\left(\mathrm{gm} \mathrm{kg}^{-1}\right)$ & 19.5 & 18.5 & 18.5 & 19 & 18 & 19.5 \\
\hline $\mathrm{CF}\left(\mathrm{gm} \mathrm{kg}^{-1}\right)$ & 3.72 & 3.72 & 3.77 & 3.65 & 3.71 & 3.76 \\
\hline $\mathrm{Ca}\left(\mathrm{gm} \mathrm{kg}^{-1}\right)$ & 1.16 & 1.08 & 1.12 & 1.08 & 1.08 & 1.13 \\
\hline $\mathrm{P}\left(\mathrm{gm} \mathrm{kg}^{-1}\right)$ & 0.58 & 0.52 & 0.55 & 0.51 & 0.52 & 0.57 \\
\hline Methionine $\left(\mathrm{gm} \mathrm{kg}^{-1}\right)$ & 0.4 & 0.4 & 0.4 & 0.4 & 0.4 & 0.4 \\
\hline Lysine $\left(\mathrm{gm} \mathrm{kg}^{-1}\right)$ & 1.00 & 0.99 & 1.01 & 1.01 & 1.01 & 1.00 \\
\hline
\end{tabular}

Added broiler premix (Renata Animal Health Ltd.) @ 250 g per 100 kg which contained: vitamin A: $4800 \mathrm{IU}$; vitamin D: $960 \mathrm{IU}$; vitamin E: $9.2 \mathrm{mg}$; vitamin $\mathrm{k}_{3}: 800 \mathrm{mg}$; vitamin $\mathrm{B}_{1}: 600 \mathrm{mg}$; vitamin $\mathrm{B}_{2}: 2$ $\mathrm{mg}$; vitamin $\mathrm{B}_{3}: 12 \mathrm{mg}$; vitamin $\mathrm{B}_{5}: 3.2 \mathrm{mg}$; vitamin $\mathrm{B}_{6}: 1.8 \mathrm{mg}$; vitamin $\mathrm{B}_{9}: 2 \mathrm{mg}$; vitamin $\mathrm{B}_{12}: 0.004$ mg; Co: $0.3 \mathrm{mg}$; Cu: $2.6 \mathrm{mg}$; Fe: $9.6 \mathrm{mg}$; I: $0.6 \mathrm{mg}$; Mn: $19.2 \mathrm{mg}$; Zn: $16 \mathrm{mg}$; Se: $0.48 \mathrm{mg}$; DL Methionine: $20 \mathrm{mg}$; L- lysine: $12 \mathrm{mg}$. 
Table 4: Growth performance of the birds fed on the experimental diets

\begin{tabular}{|c|c|c|c|c|c|}
\hline \multirow[t]{2}{*}{ Treatments } & \multicolumn{2}{|c|}{ Average body weight $(\mathrm{g})$} & \multirow{2}{*}{$\begin{array}{c}\text { Average } \\
\text { weight gain } \\
\text { (g) }\end{array}$} & \multirow{2}{*}{$\begin{array}{l}\text { Total feed } \\
\text { Intake (g) }\end{array}$} & \multirow[t]{2}{*}{ FCR } \\
\hline & Initial & Final & & & \\
\hline $\mathrm{T}_{0}$ & 242.8 & 1550.0 & 1307.20 & 2350 & 1.83 \\
\hline $\mathrm{T}_{1}$ & 255.0 & 1600.0 & 1500.00 & 2700 & 1.80 \\
\hline $\mathrm{T}_{2}$ & 245.0 & 1650.0 & 1405.00 & 2550 & 1.81 \\
\hline $\mathrm{T}_{3}$ & 260.0 & 1750.0 & 1490.0 & 2500 & 1.67 \\
\hline $\mathrm{T}_{4}$ & 262.5 & 1850.0 & 1587.50 & 2600 & 1.63 \\
\hline $\mathrm{T}_{5}$ & 240.5 & 1500.50 & 1259.5 & 2400 & 1.90 \\
\hline
\end{tabular}

Table 5: Serum lipid parameters in broilers fed different levels of MLM supplemented diets

\begin{tabular}{|c|c|c|c|c|c|c|c|c|}
\hline \multirow[t]{2}{*}{ Items } & \multirow{2}{*}{$\begin{array}{l}\text { Day } \\
\text { s }\end{array}$} & \multicolumn{6}{|c|}{ Dietary level of MLM } & \multirow[b]{2}{*}{$\begin{array}{l}\text { Level } \\
\text { of } \\
\text { Signif } \\
\text { icance }\end{array}$} \\
\hline & & $\begin{array}{c}\mathrm{T}_{0} \\
\text { (control) }\end{array}$ & $\begin{array}{c}\mathrm{T}_{1} \\
(2.5 \%)\end{array}$ & $\begin{array}{c}\mathrm{T}_{2} \\
(3.5 \%)\end{array}$ & $\begin{array}{c}\mathrm{T}_{3} \\
(4.5 \%)\end{array}$ & $\begin{array}{c}\mathrm{T}_{4} \\
\text { (Extract) }\end{array}$ & $\begin{array}{c}\mathrm{T}_{5} \\
\text { (Antibiotic) }\end{array}$ & \\
\hline \multirow{4}{*}{$\begin{array}{l}\text { Total } \\
\text { Cholester } \\
\text { ol } \\
\left(\mathrm{mg} \mathrm{dl}^{-1}\right)\end{array}$} & $10-$ & $197.0^{\mathrm{a}}$ & $182.0^{\mathrm{a}}$ & $173.3^{\mathrm{b}}$ & $174.0^{\mathrm{a}}$ & $181.7^{\mathrm{a}}$ & $185.3^{\mathrm{a}}$ & NS \\
\hline & 15 & \pm 14.10 & \pm 4.58 & \pm 15.69 & \pm 9.53 & \pm 6.50 & \pm 24.00 & \\
\hline & $\begin{array}{l}15- \\
22\end{array}$ & $\begin{array}{l}182.0^{\mathrm{a}} \\
\pm 9.16\end{array}$ & $\begin{array}{l}111.3^{c} \pm 13 \\
.65\end{array}$ & $\begin{array}{l}125.3^{\mathrm{b}} \pm \\
4.04\end{array}$ & $\begin{array}{l}120.7^{\mathrm{bc}} \pm 11 \\
.5\end{array}$ & $\begin{array}{l}120.7^{\mathrm{bc}} \pm 5 \\
03\end{array}$ & $\begin{array}{l}171.7^{\mathrm{a}} \\
\pm 7.63\end{array}$ & $* *$ \\
\hline & $\begin{array}{l}22- \\
42\end{array}$ & $\begin{array}{l}168.0^{\mathrm{a}} \pm \\
6.24\end{array}$ & $\begin{array}{l}141.7^{\mathrm{bc}} \pm 6 \\
.65\end{array}$ & $\begin{array}{l}111.67^{\mathrm{d}} \pm \\
6.42\end{array}$ & $\begin{array}{l}130.7^{\mathrm{c}} \pm 30 \\
23\end{array}$ & $\begin{array}{l}116.3^{c} \pm \\
7.50\end{array}$ & $\begin{array}{l}164.3^{\mathrm{ab}} \pm 10 \text {. } \\
69\end{array}$ & $*$ \\
\hline \multirow{3}{*}{$\begin{array}{l}\text { HDL- } \\
\text { Cholester } \\
\text { ol } \\
\left(\mathrm{mg} \mathrm{dl}^{-1}\right)\end{array}$} & $10-$ & $\begin{array}{l}43.33^{\mathrm{a}} \\
+2.88\end{array}$ & $\begin{array}{l}49.00^{\mathrm{a}} \pm 6 . \\
08\end{array}$ & $\begin{array}{l}38.33^{\mathrm{a}} \\
+4.16\end{array}$ & $48.33^{\mathrm{a}}$ & $46.00^{\mathrm{a}}$ & $51.33^{\mathrm{a}}$ & NS \\
\hline & $\begin{array}{l}15- \\
22\end{array}$ & $\begin{array}{l}56.33^{\mathrm{a}} \\
\pm 8.14\end{array}$ & $\begin{array}{l}52.33^{\mathrm{ab}} \pm 8 \\
.73\end{array}$ & $\begin{array}{l}48.00^{\mathrm{ab}} \pm 2 . \\
64\end{array}$ & $\begin{array}{l}48.67^{\mathrm{ab}} \pm 7 \\
02\end{array}$ & $\begin{array}{l}47.67^{\mathrm{ab}} \pm 5 . \\
03\end{array}$ & $\begin{array}{l}42.67^{\mathrm{a}} \\
\pm 2.51\end{array}$ & NS \\
\hline & $\begin{array}{l}22- \\
42\end{array}$ & $\begin{array}{l}46.00^{\mathrm{ab}} \pm \\
3.51\end{array}$ & $\begin{array}{l}50.70^{\mathrm{b}} \\
\pm 1.52\end{array}$ & $\begin{array}{l}52.00^{\mathrm{a}} \\
\pm 3.78\end{array}$ & $\begin{array}{l}48.00^{\mathrm{b}} \\
\pm 4.58\end{array}$ & $\begin{array}{l}51.00^{\mathrm{a}} \pm \\
6.65\end{array}$ & $\begin{array}{l}45.00 \mathrm{~b} \pm \\
6.24\end{array}$ & $*$ \\
\hline \multirow{3}{*}{$\begin{array}{l}\text { Triglycer } \\
\text { ide } \\
\left(\mathrm{mg} \mathrm{dl}^{-1}\right)\end{array}$} & $\begin{array}{l}10- \\
15\end{array}$ & $\begin{array}{l}82.00^{\mathrm{a}} \pm \\
6.55\end{array}$ & $\begin{array}{l}94.33^{\mathrm{a}} \pm 14 \\
.64\end{array}$ & $\begin{array}{l}89.00^{\mathrm{a}} \\
\pm 2.00\end{array}$ & $\begin{array}{l}74.0^{\mathrm{a}} \\
\pm 9.53\end{array}$ & $\begin{array}{l}83.33^{\mathrm{a}} \\
\pm 4.50\end{array}$ & $\begin{array}{l}85.3^{\mathrm{a}} \\
\pm 24.00\end{array}$ & NS \\
\hline & $\begin{array}{l}15- \\
22\end{array}$ & $\begin{array}{l}81.33^{\mathrm{a}} \pm \\
1.52\end{array}$ & $\begin{array}{l}62.33^{\mathrm{a}} \\
\pm 5.85\end{array}$ & $\begin{array}{l}73.67^{\mathrm{a}} \\
\pm 5.68\end{array}$ & $\begin{array}{l}76.7^{\mathrm{bc}} \pm \\
11.59\end{array}$ & $\begin{array}{l}72.50^{\mathrm{a}} \\
\pm 3.60\end{array}$ & $82.0^{\mathrm{a}} \pm 9.16$ & $*$ \\
\hline & $\begin{array}{l}22- \\
42\end{array}$ & $\begin{array}{l}102.0^{c} \pm \\
3.00\end{array}$ & $\begin{array}{l}77.00^{\mathrm{c}} \pm 10 \\
.96\end{array}$ & $\begin{array}{l}79.00^{\mathrm{c}} \\
\pm 4.58\end{array}$ & $\begin{array}{l}80.7^{\mathrm{c}} \\
\pm 30.23\end{array}$ & $\begin{array}{l}82.00^{\mathrm{c}} \\
\pm 7.54\end{array}$ & $\begin{array}{l}104.3^{\mathrm{ab}} \pm 10 \\
69\end{array}$ & $*$ \\
\hline
\end{tabular}

Different letters in Values are expressed as mean \pm standard error of at least three replications each of which contains eight birds. Different letters in a row differ statistically significant $(\mathrm{P}<0.05)$. Similar letters in a row statistically non- significant $(\mathrm{P}>0.05)$. 